\title{
Branding a Cool Celebrity President: Popular Music, Political Advertising, and the 2012 Election
}

\author{
JOANNA LOVE
}

During the 2008 American presidential campaign, Senator John McCain attempted to twist the widespread popularity and likability of his opponent, Senator Barack Obama, into a caricature of a frivolous and "intellectually hollow" celebrity. ${ }^{1}$ In a move later criticized for its overt mudslinging, McCain personally endorsed a commercial titled "Celebrity" that pictured Obama opposite the trainwreck pop princess Britney Spears and party-girl heiress Paris Hilton (Figure 1).
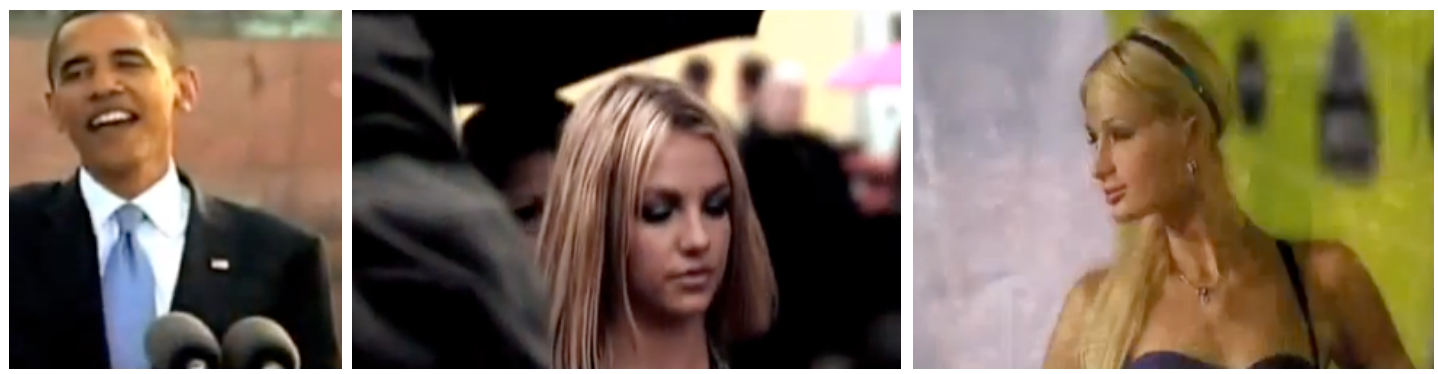

Figure 1: Commercial stills: 2008 Obama "Celebrity" Commercial, Endorsed by John McCain. John McCain 2008, “Celebrity,” 2008.

Set to the rhythmic chanting of Obama's name, the spot features images of the Illinois senator at a rally in Berlin, Germany. ${ }^{2}$ The sights and sounds of the paparazzi's cameras accompany a montage of Obama's face spliced between images of Spears and Hilton. A voiceover declares, "He's the biggest celebrity in the world, but is he ready to lead?" The commercial continues, "With gas prices soaring, Barack Obama says 'no' to offshore drilling? And says he'll raise taxes on electricity?" To punctuate the implied gravity of these questions, the pounding of a bass drum silences the presumably brainwashed and star-struck chanting crowd. Only the punch line is left to round out the spot: "Higher taxes. More foreign oil. That's the real Obama."

\footnotetext{
${ }^{1}$ Sam Stein, "McCain Ad Links Paris Hilton, Britney Spears To Obama," Huffington Post, August 7, 2008, http://www.huffingtonpost.com/2008/07/30/mccain-ad-links-paris-hil_n_115841.html.

${ }^{2}$ The chanting footage was taken from Obama's 2008 trip to Berlin, where about 200,000 Germans turned out to hear his speech. The adoration given to him by the people of Berlin attracted media attention because, as one political writer put it, "The event minted Obama's reputation as a political rock star, one capable of charming the masses at home and abroad." Cameron Abadi, “Obama Ist Klein Berliner: Fifty Years after JFK's Visit, and Five Since His Own, Obama Returns to Berlin—to a Much Different Mood,” New Republic, June 18, 2013, http://www.newrepublic.com/article/113544/obamasberlin-visit-2013-wont-be-anything-2008.
} 
When asked to comment on the commercial's portrayal of him as a shallow and irresponsible media star, Obama refused. ${ }^{3}$ Instead, the Illinois senator stated that McCain spent too much time talking negatively about his opponent and that someone should ask the Arizona senator where he stood on the campaign's issues. ${ }^{4}$ In the end, calling attention to Obama's high public profile proved fruitless for McCain and his party as Obama went on to win the presidency. Media theorist Douglas Kellner analyzed this as part of the political "celebrity spectacle" that engulfed the 2008 presidential race. In his discussion of the media attention that surrounded Obama, Kellner pointed out: "[q]uite obviously, the Republicans did not understand that Obama's rising celebrity status was helping him become more popular, getting him more attention, support and, eventually, votes from a population that is generally attracted by celebrity status and culture." $\mathrm{5e}$ thus surmised that any and all attention paid to Obama's celebrity status ultimately helped him to win his first presidency.

Fast forward to President Obama's 2012 re-election campaign. Four years later, Obama openly embraced the celebrity status he had acquired during his first term in office. Throughout the term, he had not only established a reputation for rubbing elbows with superstar musicians (like Beyoncé and Jay-Z), actresses (Eva Longoria and Ellen DeGeneres), and even fashion designers (Michael Kors), but also for being fluent in popular culture and its trends. Obama noticeably went above and beyond former president Bill Clinton's iconic saxophone rendition of "Heartbreak Hotel" on The Arsenio Hall Show two decades prior and allowed the media to film him participating in numerous pop-cultural events. ${ }^{6}$ These included a friendly round of basketball, dancing, singing, appearing on multiple talk shows, and even drinking a beer in public. Never before had there been an American president who so convincingly expressed a sincere (and public) affinity for so many facets of popular culture and successfully wielded such a myriad of its signifiers as cultural capital to win the affections of "the masses." Obama thus used media attention to fashion himself as "cool" to the American public. Thomas Frank locates the "hip" and the "cool" in music and imagery that have proved central to national brand advertising since the rise of the baby boomer counterculture in the 1960s (which, incidentally, is the generation to which Obama belongs). ${ }^{8}$ In the decades since, these traits have been attached to corporate products to convey overarching concepts of "youthfulness" and "energy."

\footnotetext{
${ }^{3}$ Paris Hilton released a tongue-in-cheek video of her own that commented on the ridiculousness of her comparison to Obama. In the video she sarcastically "accepts" McCain's “endorsement" for her as president and questions his ability be an effective leader. She even mockingly labels him as "old enough to remember when dancing was a sin." "Paris Hilton Responds to McCain Ad," Funny or Die, August 5, 2008, http://www.funnyordie.com/videos/64ad536a6d/paris-hilton-responds-to-mccain-ad-from-paris-hilton-adam-ghost-panthermckay-and-chris-henchy?playlist $=210399$.

${ }^{4}$ Stein, "McCain Ad," Huffington Post.

${ }^{5}$ Douglas Kellner, "Barack Obama and Celebrity Spectacle," International fournal of Communication 3 (2009): 722.

${ }^{6}$ Clinton was running for his first presidential term at the time of his appearance on Hall's show. "Clinton Appearance on Arsenio Hall Show," C-Span, June 3, 1992, http://www.c-span.org/video/?26472-1/clinton-appearance-arsenio-hall-show.

${ }^{7}$ For more on Obama's connection to popular culture see: Nicholas A. Yanes and Derrias Carter, eds., The Iconic Obama 2007-2009: Essays on Media Representations of the Candidate and New President (Jefferson: McFarland \& Company, 2012).

${ }^{8}$ In chapter eight of The Conquest of Cool, Frank discusses Pepsi-Cola's attempt to entice the 1960s counterculture demographic by working to replicate aspects of their presumed lifestyle through fast-paced images and energetic music. This demonstrates the company's belief that they could attract young consumers with tropes that "defined" their generation-i.e., those that were "hip" and "cool." In the decades since, marketers have continued to use these tactics. See Thomas Frank, The Conquest of Cool: Business Culture, Counterculture, and the Rise of Hip Consumerism (Chicago: University of Chicago Press, 1997), 168-183, http://dx.doi.org/10.7208/chicago/9780226924632.001.0001.

${ }^{9}$ Frank notes that from the 1960s onward, PepsiCo., Inc. used these words to describe their target audience. The Conquest of Cool, 168-183.
} 
In the pages below, I extend both Kellner's notion of the political "celebrity spectacle" and Frank's concept of "cool" to argue that it was a combination of the two-what I call Obama's "cool celebrity"that many advertising campaigns both for and against the president embraced in his 2012 race against Mitt Romney. ${ }^{10}$ Both parties either explicitly or implicitly used this terminology in their commercials, linking Obama's "coolness" to his youthfulness, energy, and celebrity status through signifiers of mainstream popular culture-specifically aural and visual tropes borrowed from mainstream popular music. ${ }^{11}$ This essay thus demonstrates how two representative Internet commercials created and circulated by supporters of both major American political parties enlisted a potpourri of pop music signifiers that worked the president's "cool celebrity" status, for better or for worse, into their agendas. And as we will see, marketers' employment of the sights and sounds of popular culture forced them (sometimes unsuccessfully) to negotiate established aesthetic boundaries between political and national brand advertising.

The first commercial examined below is titled "We Are a Powerful Force." ${ }^{12}$ This spot proved characteristic of those created by the pro-Obama camp as it played-up his cool celebrity persona and highlighted his 2012 campaign slogan, "Forward" (Figure 2). ${ }^{13}$

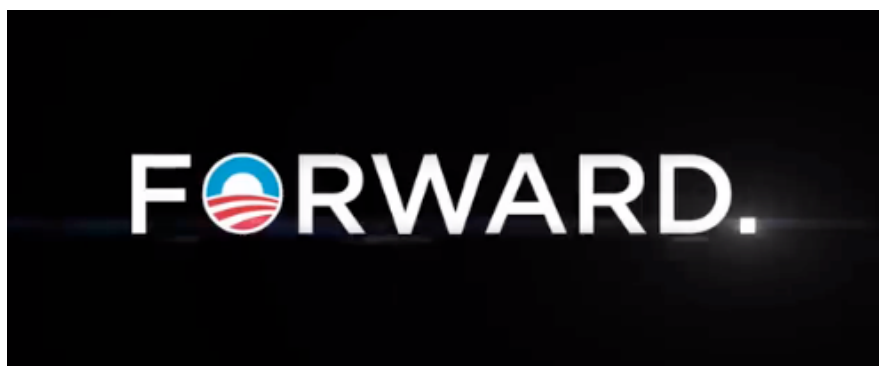

Figure 2: Commercial still: Obama's 2012 Campaign Slogan ${ }^{14}$

\footnotetext{
${ }^{10}$ I choose to use term "cool" over "hip" throughout this essay for a few reasons. Most obviously, the word "cool" is specifically used in the commercials I discuss and in viewer commentary. While concepts of hipness and coolness are intertwined, and hipness certainly plays a role in these commercials, it is not my goal here to rehash the perilousness of hip ideology, which as Phil Ford points out, evaporates the moment it is defined. Space considerations therefore prevent my reading here from being concerned with the semantics or aesthetics of hip terminology. Instead, I am interested in connecting the practices used in these commercials with advertising's long history of using images and sounds marketers have been more generally identified as cool (trendy) to market corporate goods. For a recent discussion on the aesthetics of hipness, see Phil Ford, Dig: Sound and Music in Hip Culture (Oxford: Oxford University Press, 2013), 3-18.

${ }^{11}$ The rise of MTV in the 1980s reformed popular music aesthetics, making them increasingly dependent on images in addition to sound. See Andrew Goodwin's discussion in Dancing in the Distraction Factory: Music Television and Popular Culture (Minneapolis: University of Minnesota Press, 1992), 24-48.

${ }^{12}$ Organizing for America, "We are a Powerful Force," YouTube video, November 2012, http://www.youtube.com/watch?v=HB7XQw3k7uc.

${ }^{13}$ Obama's "branding" was engineered by GGMB, a marketing firm that claims social and political motivation for their work. Refer to http://www.gmmb.com/about/. Jim Margolis was the head of Obama's media team for the 2012 campaign. For more on his role, see Jeremy W. Peters, "Aggressive Ads for Obama at the Ready," New York Times, May 8, 2012, http://www.nytimes.com/2012/05/09/us/politics/obamas-media-team-has-aggressive-ads-at-theready.html?pagewanted $=$ all\&_r $=1 \&$.

${ }^{14}$ Rachel Weiner, "Obama unveils new campaign slogan: 'Forward,” The Washington Post, last modified April 30, 2012, http://www.washingtonpost.com/blogs/the-fix/post/obama-unveils-new-campaign-sloganforward/2012/04/30/gIQA3SrbrT blog.html.
} 
Marketers focused "We Are a Powerful Force" (and countless others like it) on celebrity endorsements by persons from marginalized groups to whom the Democratic Party actively targeted for votes. These groups included youth, women (especially single mothers), and Latino, African American, Asian American, and LGBTQ communities. By directing their commercials at these constituents, marketers defined the president as a "superstar" for civil rights (a tactic that paid off handsomely according to demographic polling information). ${ }^{15}$ Obama's supporters therefore created a vivid picture of a human and humane president who would continue to be an effective leader. Many commercials depicted him as a civil rights proponent who openly backed LGBTQ causes, a hero for the struggling middle class who proposed student loan breaks and aid for struggling home and business owners, and a victorious commander-inchief who took down public enemy number one, Osama Bin Laden. ${ }^{16}$

Not surprisingly, commercials created by Republican supporters depicted the President from the opposite vantage point. The second spot I examine below intended to foil the Democratic Party's positive portrayal of their cool celebrity candidate. This commercial, literally titled "Cool," acted as a sequel to McCain's 2008 "Celebrity" spot. ${ }^{17}$ In this context the word "cool" was meant to take on a negative connotation. This and other pro-Romney spots attempted to play up the potentially problematic qualities of Obama's celebrity coolness and bring his effectiveness into question. "Cool" criticized his constant presence in the public eye and suggested that Obama's time on camera took his focus away from issues plaguing the American people, specifically those associated with the country's flailing economy. Opponents therefore viewed Obama's celebrity image as a fault and dramatized the notion that his fame would ultimately bring him down at the expense of the entire country.

I focus this essay on "We Are a Powerful Force" and "Cool" because they are notable in their foregrounding of mainstream musical tropes-including specific timbres, rhythms, forms, styles, melodies, harmonies, and images - to brand the president's cool celebrity status in ways that aligned with each commercial's agenda. The prominent use of popular music signifiers in the 2012 presidential campaign was logical considering that much of the media spectacle cultivated around Obama dealt with his musical tastes. As Dana Gorzelany-Mostak points out, Obama noticeably set himself apart in both presidential races with his public affinity for music, namely those styles of music historically regarded as African American, such as hip-hop and soul. ${ }^{18}$ What made popular music further appropriate for his agenda was the fact that, unlike the highbrow connotations suggested by classical music timbres and styles, many pop genres spoke through and to the president's targeted voter demographics-i.e., marginalized populations. ${ }^{19}$ Perhaps even more important for the intended target audiences of both commercials examined here, popular music has been associated with youth culture since the mid-1950s. From that point on, marketers have successfully persuaded baby boomers and successive generations with the very

\footnotetext{
${ }^{15}$ Dr. Diana E. Sheets discusses how Obama beat Romney with support from key groups of minority voters. See “Obama's 2012 Victory: The Demographic Becomes the Narrative," Huffington Post, December 21, 2012,

http://www.huffingtonpost.com/dr-diana-e-sheets/obamas-2012-victory-the-demographic-becomes-thenarrative_b_2341438.html.

${ }_{16}$ Jana Kasperkevic, "Another Day, Another Ad, Another Celebrity Endorsement," Houston Chronicle, October 18, 2012, http://blog.chron.com/txpotomac/2012/10/when-it-comes-to-campaign-ads-barack-obama-is-the-celebritypresident/\#7972101=0. Refer to the various commercials featured on this page, especially "Challenges" and "Women's Voices."

${ }^{17}$ American Crossroads, "Cool," YouTube video, April 26, 2012, http://www.youtube.com/watch?v=lhXGkeMdOJs.

${ }^{18}$ Gorzelany-Mostak, "Keepin' it Real (Respectable) in 2008: Barack Obama's iPod as Proof of Cultural Blackness," (unpublished manuscript, 2012).

${ }^{19}$ Consider, for example, early disco's relationship to LGBT communities, pop to young girls and women, heavy metal to adolescent men, and as already mentioned, early hip-hop and soul to African American and Latino groups.
} 
rock and pop music they enjoyed. ${ }^{20}$ Not coincidentally, both 2012 presidential candidates were from that generation, making the prominent place of popular music in their campaigns further relatable to them and their constituents. ${ }^{21}$

\section{Political Advertising in the Obama Years}

For approximately forty years, cultural theorists have argued that most national brand advertising borrows cultural forms to fit the qualities marketers map onto inanimate corporate products. In the 1970s Judith Williamson used the term re-presentation to describe how advertisers positioned ideas, objects, and/or people in commercial contexts to generate new meanings. ${ }^{22}$ Raymond Williams weighed in soon after, calling advertising a "magical" system, a "cultural pattern," and a "highly organized and professional system of magical inducements and satisfactions." 23 By the mid-1980s, Michael Schudson noticed that few forms of artistic output were off limits to marketing agendas and posited that ". . abstraction is essential to the aesthetic and intention of contemporary national consumer-goods advertising." ${ }^{24}$ His theories suggested that much like socialist art, U.S. visual art forms had fallen victim to what he called "capitalist realism." ${ }^{25}$ With regard to popular music's role in commercials, Timothy D. Taylor and Bethany Klein have documented the noticeable shift towards using both old and new rock and pop songs in national advertising campaigns in an attempt to lend cultural credibility to products. ${ }^{26}$ Pepsi-Cola campaigns in the mid to late 1980s provide a pioneering example of this, as they were the first to use select fragments from the latest radio hits with the intent to convince audiences that consuming their product would include them in a youthful and cool generation rich in pop cultural capital. ${ }^{27}$ In the twenty-first century, the use of popular music in commercials has exponentially increased as marketers now regularly rely on pre-existing songs to "sonically brand" corporate products and to attract young and trendy audiences. ${ }^{28}$

\footnotetext{
${ }^{20}$ Frank, The Conquest of Cool, 168-183.

${ }^{21}$ Baby boomers originally placed popular music in television commercials and continue to be the generation that purchases the most music. Timothy D. Taylor discusses how baby boomers had become the tastemakers in the advertising industry in the 1990s and were responsible for putting electronica music into commercials for the first time. See "The Changing Shape of the Culture Industry; or, How Did Electronica Music Get into Television Commercials?” Television E New Media (2007): 235258, http://dx.doi.org/10.1177/1527476407301837.

${ }^{22}$ Williamson, Decoding Advertisements: Ideology and Meaning in Advertising (London and New York: Marion Boyars, 1978), 177.

${ }^{23}$ Williams, “Advertising: The Magic System," in Media Studies: A Reader, ed. Paul Marris and Sue Thornham (New York: New York University Press, 2000), 704-709.

${ }^{24}$ Schudson, Advertising, the Uneasy Persuasion: Its Dubious Impact on American Society (New York: Basic Books, 1984$), 214$.

${ }^{25}$ Ibid., 214.

${ }^{26}$ See especially chapters 7 through 9 of Taylor, The Sounds of Capitalism: Advertising, Music, and the Conquest of Culture (Chicago: University of Chicago Press, 2013), 179-246. See also Klein's discussion of the licensing and aesthetic consequences of popular music in advertising in As Heard on TV: Popular Music in Advertising (Burlington: Ashgate Publishing Company, 2009).

${ }^{27}$ Frank, The Conquest of Cool, 168-183.

${ }^{28}$ Sonic branding has become an essential marketing practice in the second decade of the twenty-first century. Devon Powers explains that it "refers to the use of sound to enhance brand awareness, appeal, and cohesion." See "Strange Powers: The Branded Sensorium and the Intrigue of Musical Sound" in Blowing up the Brand: Critical Perspectives on Promotional Culture, eds. Melissa Aronczyk and Devon Powers (New York: Peter Lang Publishing, 2010), 285-306. Leslie M. Meier examines contemporary sonic branding in "Promotional Ubiquitous Musics: Recording Artists, Brands, and "Rendering Authenticity," Popular Music and Society 34, 4 (2011), 399-415, http://dx.doi.org/10.1080/03007766.2011.601569. For international musicological approaches to the use of pre-existing music in commercials see Music in Advertising: Commercial Sounds in Media Communication and Other Settings, eds. Nicolai Graakjaer and Christian Jantzen (Aalborg: Aalborg University Press, 2009).
} 
Political advertising, however, has not followed the same rules as national brands since at least Ronald Regan's groundbreaking "Morning in America" spot, when the music and visuals became decidedly more cinematic while contributing to more subtle and nuanced implications about what the candidate could offer the American "way of life." 29 Subsequently, the majority of political commercials tended to feature production music that adhered to more "serious" (i.e. classical and European) musical styles, instruments, and timbres. Most intentionally left out the overtly playful or trendy elements of American pop culture signifiers in favor of documentary-like images and highbrow Western-art musical timbres. So, despite the fact that presidential candidates had circulated slogans featuring the tunes, timbres, rhythms, and forms that borrowed from contemporary popular styles since the early years of the twentieth century, popular music did not noticeably make its way into political television commercials until the first decade of the new millennium. ${ }^{30}$

As political theorists have discussed at length, the sights and sounds of political campaigning changed considerably with Barack Obama's 2008 campaign. From the very start, Obama had successfully integrated popular culture media and tropes into his politics. While he was not by any means the first to use a catchy pop song on the campaign trail, he was the first to make a calculated effort to steep his image and presidency in diverse aspects of contemporary American culture. In an essay appropriately titled "Popular Culture in the Age of Obama," Angela Nelson summed up her analysis of the 2008 campaign, saying: "Obama has made peace with popular culture and has used it to his advantage." 31 Hence, the marketing of Obama as a cool celebrity fell easily within what Kellner dubbed the "media spectacle." He posited:

In the contemporary era, politics is thus becoming a mode of spectacle in which the codes of media culture determine the form, style, and appearance of presidential politics, and party politics in turn becomes more cinematic and spectacular in the sense of Guy Debord's concept of spectacle. Consequently, US presidential politics of the past several decades can be perceived as media spectacles, in which media politics becomes a major constituent of presidential elections, governance, and political success or failure. ${ }^{32}$

Kellner elaborated that it was this media spectacle to which both parties participated and contributed in the 2008 election, arguing, "Barack Obama ... has become a master of the spectacle and global celebrity of the first rank."33

Consequently, for the 2012 elections, marketers behind both party lines had the unique task of taking the traits Obama had already established for himself and transforming publically recognized elements of his celebrity iconicity into signifiers for his image, and not the other way around. Instead of haphazardly mapping convenient tropes onto the president (the practice employed by commercials for household commodities and many former politicians), a majority of the spots about Obama worked with the aural and visual pop culture signifiers previously associated with him. In their foregrounding of these

\footnotetext{
29 “Ronald Reagan TV Ad: 'It's morning in America again,”' YouTube video, November 12, 2006, http://www.youtube.com/watch?v=EU-IBF8nwSY.

${ }^{30}$ A notable example is "Keep Cool and Keep Coolidge" from 1924, set in the style of vaudeville songs. The video can be watched online in "A History of Campaign Songs," Consequence of Sound, November 5, 2012, http://consequenceofsound.net/2012/11/a-history-of-presidential-campaign-songs/2/.

${ }^{31}$ Nelson, "Popular Culture in the Age of Obama," in Yanes and Carter, The Iconic Obama, 14.

${ }^{32}$ Kellner, Media Spectacle (New York: Routledge, 2003), 160. My emphasis. Kellner explains that he expands on Guy Debord's use of the term "spectacle," re-defining it as "those phenomena of media culture which embody contemporary society's basic values, serve to enculturate individuals into its way of life, and dramatize its controversies and struggles, as well as its modes of conflict resolution." 2.

${ }^{33}$ Kellner, "Barack Obama and the Celebrity Spectacle," 717 (my emphasis).
} 
tropes, many of the commercials made for the 2012 presidential campaign therefore proved innovative in their inclusion of well-worn national brand advertising practices that borrowed elements of "coolness" and celebrity culture to attract young and savvy audiences. Election marketers and the production music companies they hired thus followed corporate advertising practices in their intention to "appellate" (grab) viewers' attention and meet their "alreadyness" (experiences) with pop music tropes in the hope that those who recognized iconic pop performers and mainstream sounds would find the commercials' "equivalences" (messages) discernable and agreeable. ${ }^{34}$

\section{"We Are a Powerful Force"}

Created by HardPin Media, "We are a Powerful Force" presents a positive and upbeat message aimed at minority women voters in Philadelphia. ${ }^{35}$ The themes of energetic youthfulness and grassroots mobilization are supported by the pop cultural tropes placed throughout the commercial. As a young African American woman, the R\&B singer Alicia Keys, embodies three of the Obama campaign's targeted voter demographics. The commercial therefore pairs visual close-ups of Keys with $\mathrm{R} \& \mathrm{~B}$, rock, and pop music tropes to sonically support her message and interactions with the other women on screen.

The spot opens with a simple title frame with muted patriotic blue and white colors that identify its sponsors (Figure 3).

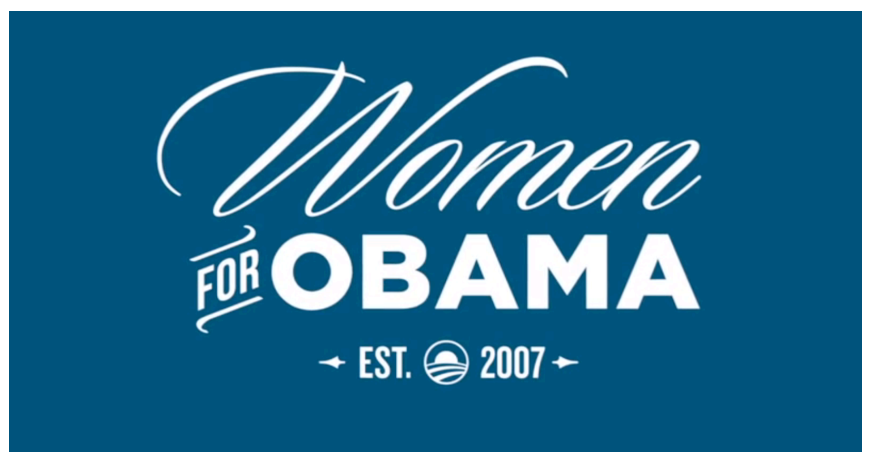

Figure 3: Commercial still: Opening Title Frame.

Organizing for Action, "We are a Powerful Force," 2012.

\footnotetext{
"Women for Obama," a division of a non-profit group called Organizing for Action (OFA), define themselves as "a network of supporters across the country who are working to re-elect the President and make sure we keep moving forward." ${ }^{36}$ Its OFA parent group, which still appears to be active since the

${ }^{34}$ Throughout this essay, I extend advertising terminology used by Robert Goldman and Stephen Papson. While they focus on visual signifiers in advertising, their terms prove relevant for investigating the roles of musical signifiers in commercials. In particular, their re-coinage of the terms "appellate" (how ads invite audiences in), "alreadyness" (viewers' ideological assumptions and experiences), and "equivalence" (the link made between the product and result promised) prove helpful for considering possible viewer relationships to these campaigns. Goldman and Papson, Sign Wars: The Cluttered Landscape of Advertising (New York: Guilford Press, 1996); and Nike Culture: The Sign of the Swoosh (London: Sage Publications, 1998$), 35$. These authors extend these terms from Judith Williamson's ideas in Decoding Advertisements, 51.

${ }^{35}$ HardPin Media claims it "spent 2012 helping drive home the narrative behind President Obama's re-election.” In addition to the Keys commercial, it also created others that similarly featured big-name celebrities. To browse their portfolio, visit: http://www.hardpinmedia.com.

${ }^{36}$ As of July 2013, Organizing for Action described its statement of purpose as: "a nonprofit organization established to
} 
election, states that it specifically advocates the agenda set forth by President Obama. In fact, the commercial was released just before a series of voter registration events sponsored by the OFA and deemed the "Weekend of Action." " Included in the policies listed as essential to the group's political aims, it specifically names "women's issues" that include equal pay and affordable healthcare. The commercial's opening title frame was therefore intended to remind viewers about Obama's stance on these policies. In the same vein, it also acted as a subtle reminder about his opponent's views and the public debate surrounding what many dubbed the Republican Party's "war on women"—a hotly debated issue that arose after multiple contentious comments and legislative actions made by key leaders in the months leading up to the 2012 election. ${ }^{38}$

The commercial's initial frames are musically supported with a major key, pop-like piano ostinato. At a mid-range tessitura, the thin piano texture cycles smoothly through a two-measure repeated figure at a prominent yet "polite" mezzo-forte level. In this way, the track is cool and laid back but also archetypically feminine, as it does not exhibit the aggressive timbres, textures, rhythms, or volume of more traditionally masculine rock forms. The image of pianist and R\&B singer Alicia Keys reinforces the spot's underlying cool and feminine musical motive. Although Keys is not shown performing, and her music does not provide the soundtrack, she visually stands as a signifier for mainstream popular music in the spot-i.e., those familiar with her and her songs know her status as a musician. The pairing of Keys's image with the aural signifier of the piano is therefore intended to appellate her fans, whose demographics are presumably similar to those both targeted and eventually pictured in the spot. Viewers' "alreadyness" with her may have included media portrayals or hearing any of her Top 40 hits including her newest single, "Girl on Fire." assumed that the rallying of Keys's fans would create a following for the advertised product, which in this case was the president. ${ }^{40}$

support President Obama in achieving enactment of the national agenda Americans voted for on Election Day 2012. OFA will advocate for these policies throughout the country and will mobilize citizens of all parties and diverse points to speak out for speedy passage and effective implementation of this program, including gun violence prevention, sensible environmental policies to address climate change and immigration reform. In addition, OFA will encourage the formation of chapters that will be dedicated at the grassroots level to this program, but also committed to identifying and working progressive change on a range of issues at the state and local level. In carrying its work, OFA will operate as a 'social welfare' organization within the meaning of section 501(c)(4) of the Internal Revenue Code." The organization has since then expanded its list of causes. See "About," Organizing for Action website, http://www.barackobama.com/about/about-ofa?source=footer-nav. For more on Women for Obama and the 2012 campaign see http://www.barackobama.com/women/accomplishments.

${ }^{37}$ Patrick Washington, “Alicia Keys: "We are a Powerful Force'-New Video from Obama for America," Dallas Weekly, September 27, 2012, http://www.dallasweekly.com/arts and entertainment/article 78d05528-08d9-11e2-aafe$0019 \mathrm{bb} 30 \mathrm{f} 31 \mathrm{a} \cdot \mathrm{html}$ ? mode $=$ image\&photo $=0$.

${ }^{38}$ Some issues included in the public debate over the perceived "war on women" were measures in states like Arizona to ban abortions; the House Republicans' push to eliminate funding for healthcare providers that administer abortions as part of their services, such as Planned Parenthood; Wisconsin Republicans' repeal of the Equal Pay Enforcement Act that permitted lawsuits over pay discrimination in state courts; and limitations on the ability of immigrants, gays, and other marginalized groups to receive justice for domestic abuse. See "The Campaign Against Women," New York Times, SR 10, May $20,2012$. Additionally, the Huffington Post provides a two-page list of articles that fall under the category "GOP War on Women": http://www.huffingtonpost.com/news/gop-war-on-women (accessed July 30, 2013).

${ }^{39}$ Keys would incidentally rework this song to sing to the president at his second inaugural ball. "Alicia Keys Performs 'Girl on Fire' at 2013 Inaugural Ball,” Vibe, January 22, 2013, http://www.vibe.com/article/alicia-keys-performs-girl-fire-2013inauguration-ball.

${ }^{40}$ For celebrity endorsements, marketers hope to "sell" the celebrity's fan base to the brand being advertised. Dallas W. Smythe argues that the mass media sells audiences like they would sell commodities to advertisers. See "On Critical and Administrative Research: A New Critical Analysis," Fournal of Communication 33 (1983): 117-127. 
Keys's coolness is visually established with her casual yet fashion-forward appearance. Her fedora, bright yellow shirt, skinny black jeans, large hoop earrings, and suede green stilettos all exemplify contemporary youthful fashion trends (Figure 4).

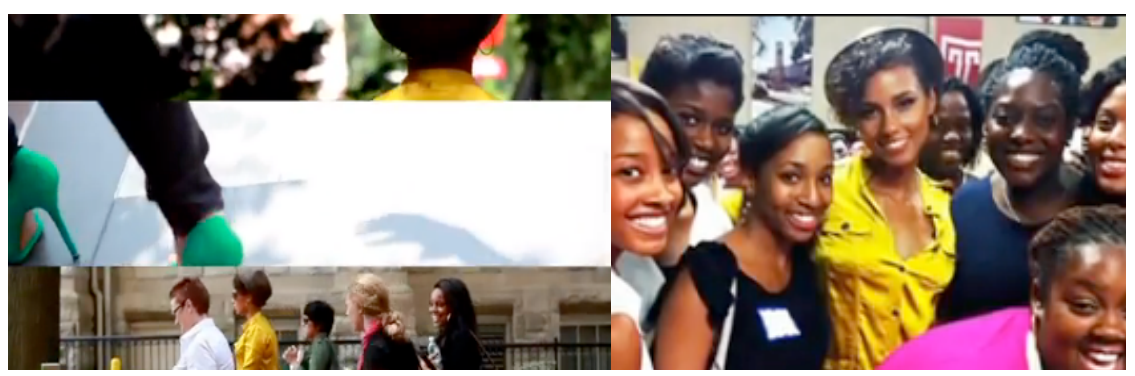

Figure 4: Commercial stills: A Montage of "Cool Celebrity" Signifiers;

Keys Poses with and Entourage of Obama Supporters.

Organizing for Action, "We are a Powerful Force," 2012.

Her language proves similarly casual, yet she is articulate and portrayed as exceedingly warm to everyone she encounters. As illustrated in the segmented first frame of Figure 4, "We are a Powerful Force" catered to the sensibilities of the notoriously hard-to-reach youth demographic by reading more like a music or YouTube video than the typical political ad: it featured fast-paced visual montages that worked to stimulate viewers who are assumed to possess ever-shortening attention spans.

Careful attention is also paid to Keys posting Twitter updates on her Apple iPhone, adding yet another layer of pop cultural co-branding to the commercial. Keys's posts frequently scroll across the screen, accompanied by candid pictures of the star with Obama's constituents, who are also presumably her fans. These images reinforce the central role that social media and technology played in the 2012 campaign and document Keys's—and by extension Obama's—grassroots efforts to entice millennials to vote for him (Figure 5). ${ }^{41}$

As the commercial unfolds, the underlying musical score perpetuates the spot's energetic visual motion with its upbeat piano ostinato and rock drum groove. The track noticeably becomes louder at key moments to lend emphasis to the spoken messages and imagery. Typical of music's role in advertising, the continuous piano and drum loops work alongside the images not only to push the commercial's momentum, but also to create anticipation and entice audiences to take action. ${ }^{42}$ This proves most essential

\footnotetext{
${ }^{41}$ Kellner discusses Obama's successful use of social media in the 2008 election saying, "Obama raised an unprecedented amount of money on the Internet, generated more than two million friends on Facebook and 866,887 friends on MySpace, and reportedly had a campaign listserv of over 10 million e-mail addresses, enabling his campaign to mobilize youth and others through text-messaging and e-mails." "Barack Obama and Celebrity Spectacle," 718. In regard to the 2012 election, Pamela Rutledge concluded that because Obama's team poured considerable money into digital campaign spending and big data analysis, he benefited from effective fundraising, voter reminders, and circulation of political issues through social media. See "How Obama Won the Social Media Battle in the 2012 Presidential Campaign," The Media Psychology Blog, January 25, 2013, http://mprcenter.org/blog/2013/01/25/how-obama-won-the-social-media-battle-in-the-2012-presidentialcampaign/.

Post-election statistics also confirm that social media proved especially useful in contributing to the success of the ideologies of participatory democracy that attracted young voters. Both Kellner and Rutledge discuss the importance of participatory democracy, which takes political commentary out of the mass media and places it in peer-to-peer relationships, thereby creating more individual and personal investments in political issues.

${ }^{42}$ Robert W. Fink correlates genres like disco and minimalism to twentieth century advertising, saying they possess "recombinant teleologies" that create desire and pleasure (jouissance) for audiences. Repeating Ourselves (Berkeley: University
} 
to the spot's climactic moment when Keys comes to the end of her speech at the Philadelphia Women's Summit (Figure 6).

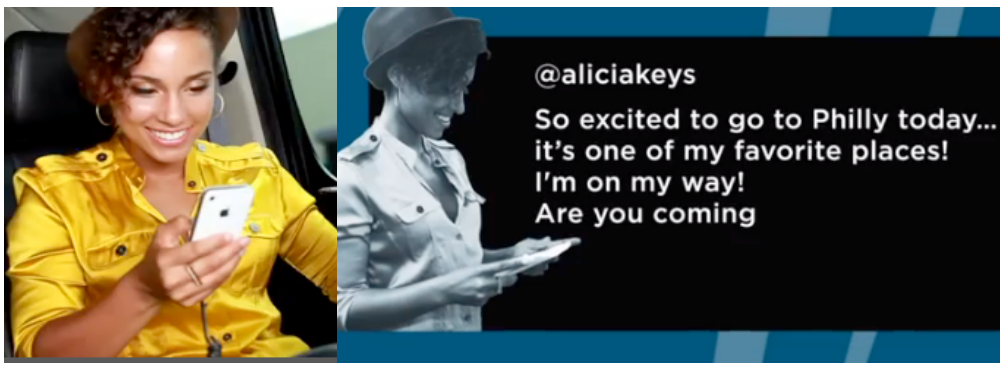

Figure 5: Commercial stills: Keys Uses Social Media to Rally Obama Supporters. Organizing for Action, "We are a Powerful Force," 2012

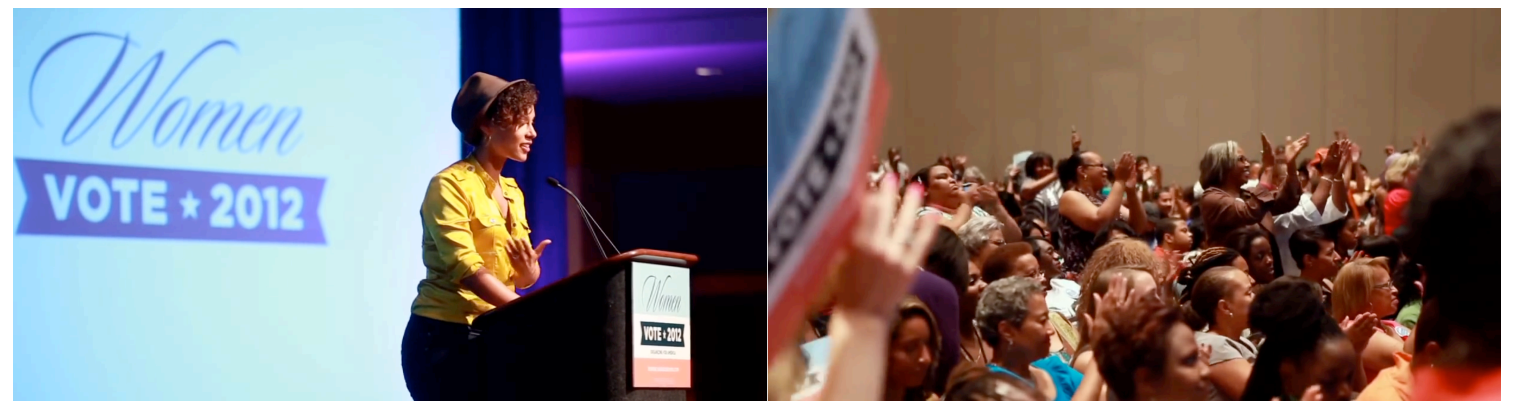

Figure 6: Commercial still: Keys Speaks at the Women's Summit in Philadelphia. Organizing for Action, "We are a Powerful Force," 2012.

After listing the "powerful women" in President Obama's family-his mother, wife, and daughters-Keys closes out the speech saying: "So now it's our turn to thank him, by voting for President Obama in November. We are a powerful force. And when powerful women get together ..." The rhetorical gesture of Keys's open-ended final phrase sends the audience to their feet. The soundtrack, which had been relegated to the background to focus viewers' attention on Keys's speech, becomes louder and is overrun by playful, whirly, synthesized sounds (notably unusual timbres in political advertising). The foregrounded synthesized motive reinforces the thunderous applause for Keys and her endorsement of Obama. A more distinct rock-drum groove and the new cyclic, synthesized pop motive then take over the track. The added synthesizer motive adds a layer of rhythmic motion and texture to the thin opening track and reinforces Obama's slogan, "Forward," by aurally pushing the momentum of Keys's message and commercial forward as well. At this point, Keys addresses the at-home viewers directly, encouraging them to get involved in grassroots efforts to support the president. It is not until the end of the spot that the

of California Press, 2005), 77, and all of chapter 3. I extend his theory here to include music's role in contemporary advertising. This commercial thus exemplifies how traditional musical teleology is avoided: there is little sense of an end "goal" or resolution until spot's conclusion. In other commercials, the music may not resolve at all, making the moment of purchase become the actual moment of closure and satisfaction. Musical tracks thus play an important role in perpetuating the state of "want" that marketers seek to create. 
energetic soundtrack finally comes to rest on the tonic chord, highlighting the "resolve" in her call to action.

Marketers at HardPin Media were skillful in foregrounding the commercial's initiative for women's rights while still making the spot about the president. Glimpses of campaign posters, mentions of his name, and pop-cultural signifiers keep him present despite the fact he is never actually shown on screen. ${ }^{43}$ Additionally, Alicia Keys's coolness, youthfulness, and celebrity were mapped onto Obama in ways that likely created an agreeable equivalence (message) for some constituents as suggested by the fact that he won the majority of votes in Pennsylvania (the state to which this commercial was targeted). ${ }^{44}$ Experienced audiences were likely aware of his affinity for popular music, his image as a youthful president, his position in a family full of strong women, and his marginality as the first African American president. Additionally, the message conveyed by Keys's journey to meet with urban constituents at a Democratic field office and her subsequent speech at a Women's Summit largely attended by (presumably) lower- to middle-class African American women suggested that despite her fame and success, she recognized that real-world inequalities still existed for marginalized populations and that she and Obama, by extension, were willing to use their celebrity to work towards moving "forward" for change. In effect, this spot attempted to demonstrate the benefits of having a cool, youthful, and energetic celebrity like Obama (mediated through Keys) as a president, namely his ability to mobilize everyone from superstars to those who are disadvantaged. And as the commercial's title suggests, together they had the potential to be a "powerful force."

The commercial incited some nationwide online chatter among members of the African American community following its debut. Media outlets including The Dallas Weekly and Rap Dose reposted "We Are a Powerful Force" to circulate Keys's call to action to their readers. ${ }^{45}$ Ebony, a magazine targeted at African American women, also featured the commercial in its online September 2012 issue with the accompanying caption, "Take it from Alicia Keys: volunteering your time and lending your voice to Obama's campaign is energizing, rewarding, and makes a real difference. ${ }^{46}$ Despite its circulation among target voters, viewers actually posted few comments about the commercial on these sites. Consequently, it is unclear whether its message was completely clear and agreeable (i.e., there was nothing to comment on), or if the spot was simply unremarkable and unconvincing, or both. One viewer suggests both readings saying, "I really admire what she did with the kids from Agabe orphanage in South Africa. Not that I give a toss about the presidential election of America. But Alicia Keys is pretty cool." ${ }^{47}$ While this viewer (who is likely from the U.K.) claims not to care about the election itself, he or she clearly understood the commercial's messages about politics, grassroots efforts for marginalized populations, celebrity endorsements, and cultural signifiers that defined what it meant to be "cool."

\footnotetext{
${ }^{43}$ Marketers had become adept at representing cultural icons without explicitly showing them onscreen since the late twentieth century. Pepsi's "The Choice of a New Generation" campaigns with Michael Jackson in 1984 exemplified this practice. See my discussion of Pepsi's depiction of Jackson through his musical and visual iconography in "From Cautionary Chart-Topper to Friendly Beverage Anthem: Michael Jackson's ‘Billie Jean' and Pepsi's 'Choice of a New Generation' Television Campaign," Fournal of the Society for American Music 9, 2 (2015): 178-203.

${ }^{44}$ NBC news reported that Obama won 52\% of the popular votes in Pennsylvania. "Presidential election results," Nbcnews.com, accessed September 1, 2013, http://elections.nbcnews.com/ns/politics/2012/all/president/\#.Uiy6iLzk-7d.

${ }^{45}$ Washington, “Alicia Keys.” “Alicia Keys: 'We Are A Powerful Force' (Obama For America)”; RapDose.com, September 27, 2012, http://rapdose.com/2012/09/27/alicia-keys-we-are-a-powerful-force-obama-for-america.

46 “[Watch] Alicia Keys' 'We are a Powerful Force,” Ebony, September 27, 2012, http://www.ebony.com/video/newsviews/watch-alicia-keys-we-are-a-powerful-force\#axzz2ePGCiJ7G.

${ }^{47}$ YouTube comment by “TheVanillatech,” November 2012, accessed May 11, 2014, http://www.youtube.com/watch?v=HB7XQw3k7uc (my emphasis).
} 


\section{“Cool"}

On the far opposite end of the spectrum, the commercial created for the American Crossroads GOP super PAC incited considerable public discourse in its attempt to undercut any positive messages conveyed by Obama's celebrity-endorsed commercials. ${ }^{48}$ Known for its affiliation with Karl Rove (former senior advisor and deputy chief of staff for George W. Bush), American Crossroads states that its mission is to raise donations for candidates who "promote people who have the courage, integrity and good ideas to get this country back on track ... They are willing to stand up for families, small businesses and communities against arrogant, power-grabbing politicians and wealthy government unions." 49 "Cool" promotes this agenda by playing up one of the bipartisan themes from the election, namely Republican accusations about the damaging effects of a "liberal media." The commercial works to dramatize and vilify the media spectacle and questions what the president had done for the very youth who had elected him four years earlier. "Cool" features a combination of pre-existing and production musics to make a mockery of Obama's cool celebrity image and to demonstrate its pitfalls. ${ }^{50}$

Visually, the spot uses crude mash-up of the president's iconic moments in office to portray him as excessive and ineffective. ${ }^{51}$ The commercial's flashy music and images work to unmask the American president's cool celebrity status by wielding pop's sonic and visual signifiers in ways that were decidedly not cool. The soundtrack is saturated with outdated 1980s-era pop cultural signifiers. Foregoing traditional political advertising practices that focus on spoken messages, the commercial is ruled by an archaicsounding, pop-infused musical track. In fact, no words other than those heard in the replay of pre-existing clips are spoken anywhere in the spot. The commercial's message is thus largely communicated through its soundtrack and occasional visual texts, many of which appear as dated neon logos (Figure 7).
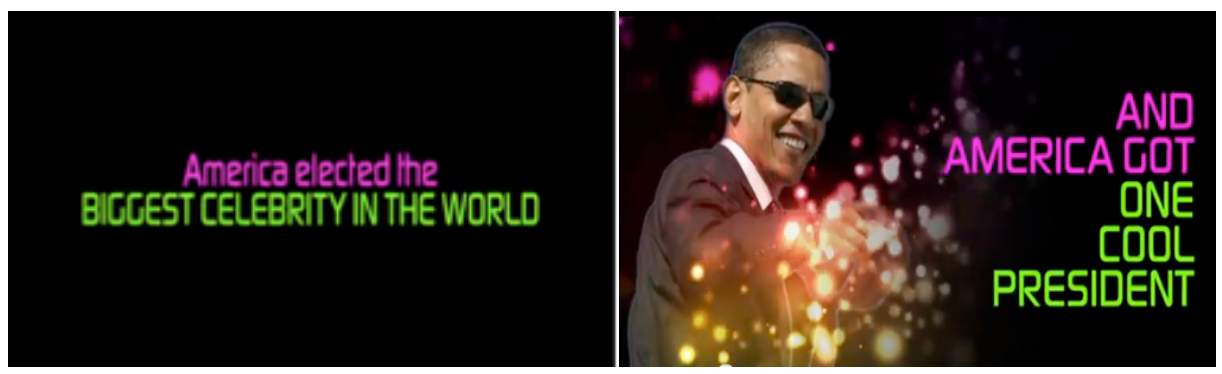

Figure 7: Commercial stills: Opening Frames. American Crossroads, "Cool” 2012.

\footnotetext{
${ }^{48}$ Although "Cool" is not specifically listed on the website, the commercial was likely created by McCarthy Hennings Media (now McCarthy Hennings Whalen, Inc.). The political and issue advertising firm lists American Crossroads as a client and cites their 2012 election commercials as part of the firm's portfolio. McCarthy Hennings Whalen, Inc., "Past and Current Clients,” accessed May 25, 2015, http://www.mhmediadc.com/clients.aspx.

${ }^{49}$ For more on their stated policies see "About," American Crossroads website, accessed June 1, 2015, http://www.americancrossroads.org/about/.

${ }^{50}$ Patrick O'Connor, a Wall Street fournal political blogger, specifically states that the super PAC ad intended to mock the “celebrity president." See "Romney Team Says Obama Campaign 'Flailing,” Washington Wire (blog), Wall Street fournal, April 27, 2012,

http://blogs.wsj.com/washwire/2012/04/27/romney-camp-says-obama-campaign-flailing/.

${ }_{51}$ Adam Goldberg, “Obama Celebrity Ad: American Crossroads 'Cool' Video Slams President Over Fame, Economy,” Huffington Post, April 26, 2012, http://www.huffingtonpost.com/2012/04/26/obama-celebrity-ad-american-crossroads-coolvideo n 1455413.html.
} 
"Cool" appellates viewers with a glitzy opening sequence accompanied by an electronic, video-gamelike ascending synthesizer riff. The soundtrack then moves to a generic, 1980s-style R\&B groove. In a manner similar to McCain's 2008 "Celebrity" spot, "Cool” features a rhythmic chanting of Obama's name to reinforce his pop-star status and once again suggest the mindlessness of his followers. Low, growling calls of "oh yeah," taken from Yello's 1985 track of the same name, are interspersed with the chanting. The pre-existing sounds are paired with equally over-the-top images of the president embracing his own stardom. In addition to the egotistical innuendos made here, "Oh Yeah" stands as an iconic cultural signifier: experienced audiences would recognize the song from its place in the cult-classic teen-slacker film Ferris Bueller's Day Off (Figure 8). ${ }^{52}$ While there are numerous connotative possibilities that the wedding of these signifiers might evoke, the most obvious one links the president to a bratty and privileged white suburban kid. Consequently, viewers" alreadyness with "Oh Yeah" as a sonic signifier might allow them to make the connection that the media attention Obama incites while participating in pop culture likens him to a frivolous, manipulative, and ultimately lazy teenager. By connecting the president to an irresponsible yet lovable kid who constantly lies to get what he wants, the sampling of this track is not only condescending, but (perhaps unintentionally) racially suggestive: it thinly veils the perpetuation of long-standing racial stereotypes that ascribe African American men with poor work ethics. $^{53}$

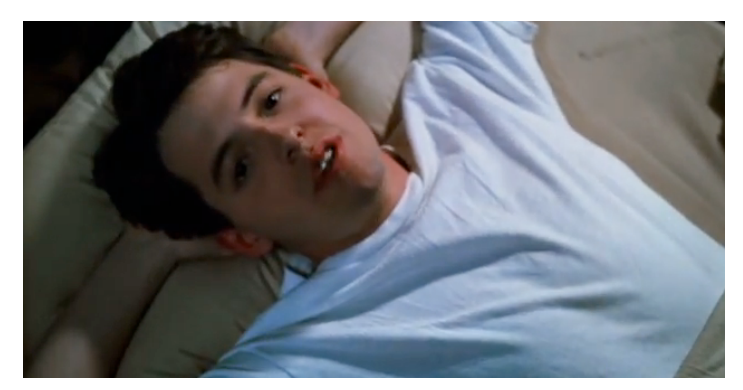

Figure 8: Film still: Musical Signifiers Characterize Obama with Ferris Bueller Paramount Pictures, Ferris Bueller's Day Off, 1986.

As the commercial continues, it is flooded with other iconic clips from the president's time in office. These moments are interspersed with dated computer graphics and supported by a flashy, overly-produced soundtrack that attempts to further complicate and damage Democrats' portrayal of Obama as a spontaneous, popular culture-loving, and musically inclined president. Among the famous moments captured in "Cool" are clips that show him enjoying a 3D movie, "slow jamming" with Jimmy Fallon on his late-night television show (Figure 9), drinking a beer in public, dancing on The Ellen DeGeneres Show,

\footnotetext{
${ }^{52}$ Yello's track is played when Ferris Bueller, the movie's protagonist, spots an expensive car owned by his best friend's dad. In the movie, this scene foreshadows Bueller's recklessness in taking the car out for a joyride and then wrecking it in an attempt to cover up his actions. Boris Blank and Dieter Meier, "Oh Yeah" (from the album Stella) performed by Yello, originally released 1985, Elektra/Asylum Records; rereleased by Polydor/Island, 2009, MP3. See also Ferris Bueller's Day Off, directed by John Hughes (1986; Los Angeles, CA: Paramount Pictures, 1999), DVD.

${ }^{53}$ Space limitations prevent me from adequately unpacking the racial undercurrents suggested by this. As I discuss in the following pages, this is only one of many unwieldy signifiers present in the commercial. For more on the complicated racial issues that arose during Obama's presidency see Patrick B. Oray's discussion about how Obama's election "brings America's color line into clearer focus." "Myth, Symbol, and the Branding of an American Presidency," in Yanes and Carter, The Iconic Obama, 32.
} 
and using his quick reflexes to kill a fly during a CNBC interview. Also included in the montage are images and sound bites of him singing Al Green's 1972 soul hit "Let's Stay Together" at a fundraising event at the iconic Apollo Theater (Figure 9) and calling rapper Kanye West a "jackass" during what was intended to be a private moment before a CNN interview. ${ }^{54}$ The dated computer graphics that accompany these defining moments where the president relaxes his inhibitions to participate in and truthfully comment on popular music (specifically African American musics) are a further attempt to trivialize him—and, presumably, popular culture by extension.

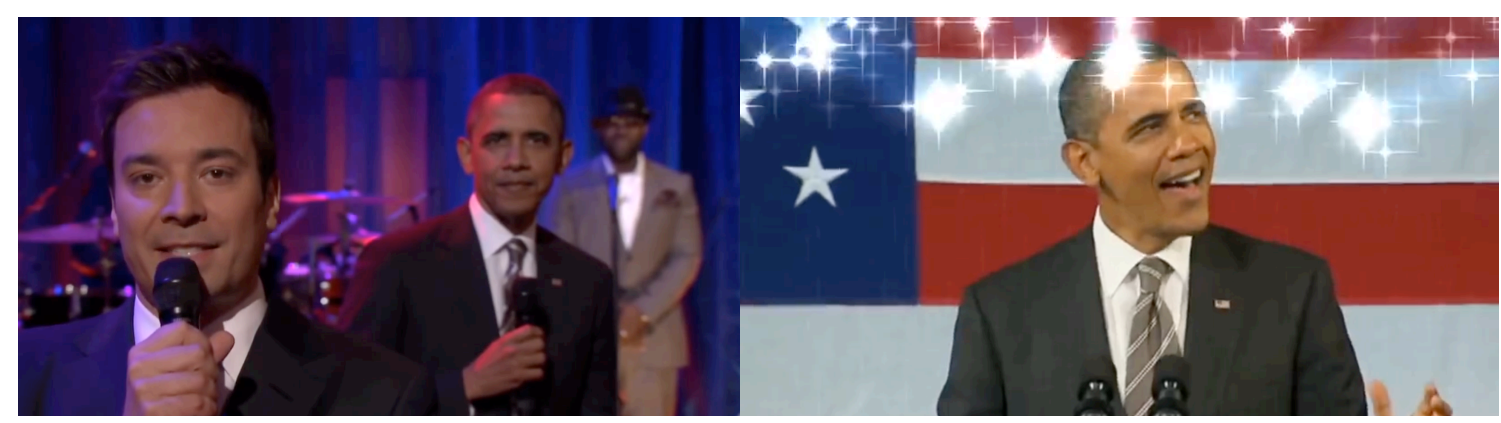

Figure 9: Commercial stills: Obama’s "Coolest" Moments Magnified with Dated Computer Graphics. American Crossroads, "Cool," 2012.

The spot's punch line follows as this colorful and upbeat mash-up abruptly cuts to a deafening silence and a fade to black-and-white images (Figure 10). Aimed at the very youth Obama attracted in his first campaign, the commercial uses stark images and the absence of sound to dramatize what its creators believed to be the consequences that recent college graduates faced as a result of electing a cool celebrity president. Disheartening economic statistics slide across the screen: " 1 in 2 recent college grads are jobless and underemployed"; " $85 \%$ moving back in with their parents"; and "Student Loan Debt exceeds one Trillion dollars" (Figure 10). ${ }^{55}$ The commercial questions the decisions made by teens and twenty somethings during the previous election, implying that their votes for a supposedly fun president have reaped a sobering black-and-white reality that includes unemployment, homelessness, and insurmountable debt.

In its final moments, the tone of the spot switches once more. "Cool" ends with a return to the opening flashy images and glitzy $R \& B$ track. The final sequence shows the comedian Jimmy Fallon welcoming a smiling Obama onto his show. A rhetorical question appears on screen to round out the spot: "After 4 Years of a Celebrity President Is Your Life Any Better?" (Figure 11). One last audible "oh yeah" transitions to a frame with the GOP super PAC's logo to suggest that it is time for Americans to elect a less glamorous and more serious president: it is time to vote Republican.

\footnotetext{
${ }^{54}$ The President's rendition of "Let's Stay Together" boosted downloads of Al Green's single that week. An article in the Huffington Post called him a "one man stimulus package for the music industry." "President Obama Sings Al Green's 'Lets Stay Together,' Sales Jump 490\%," Huffington Post, January 27, 2012, http://www.huffingtonpost.com/2012/01/27/presidentobama-sings-al-green-lets-stay-together-sales-jump_n_1236428.html. Obama was filmed making the derogatory comment about hip hop artist Kanye West after West cut off Taylor Swift's acceptance speech for Best Female Video at the 2009 MTV Video Music Awards.

${ }^{55}$ Ibid.
} 


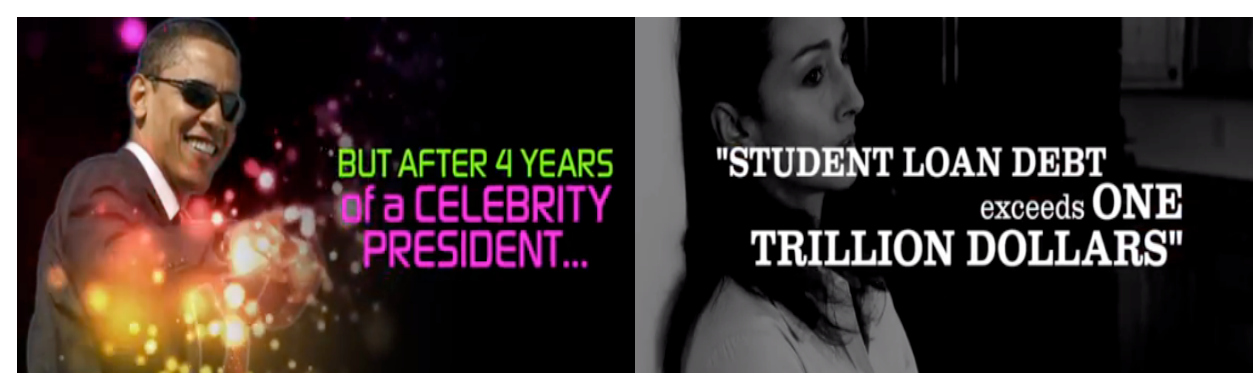

Figure 10: Commercial still: Color $=$ Fantasy of the Cool Celebrity; Black and White $=$ Sobering Reality American Crossroads, "Cool," 2012.

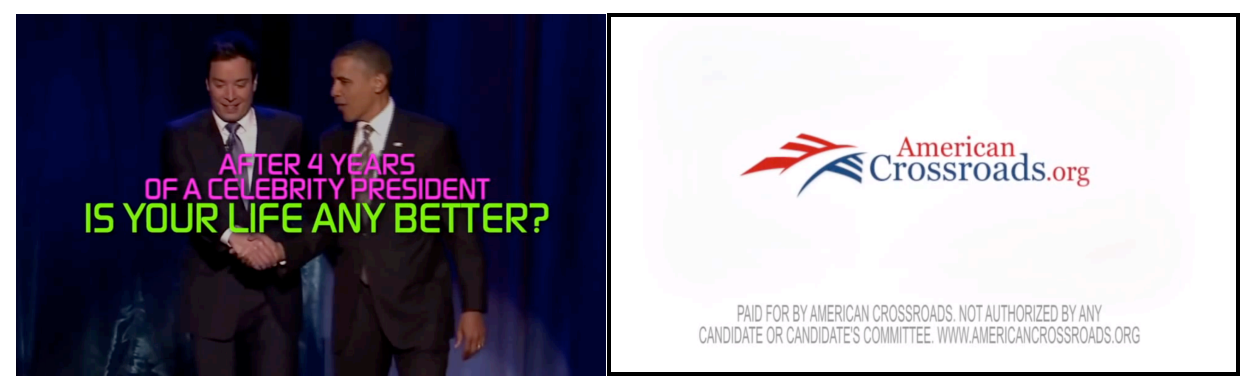

Figure 11: Commercial stills: The Price of Obama's Cool Celebrity Status. American Crossroads, "Cool," 2012.

Immediately following its debut on the Internet, "Cool" received considerable attention from supporters of both parties. The Wall Street Journal noted that "Cool" reached second place in the Web-ad charts in its first week with 358,146 views. ${ }^{56}$ Online commentary gave it mixed reviews. Some viewers agreed with it, questioning the president's decorum in appearing on television shows. ${ }^{57}$ Republican political commentator Patrick O'Connor thought the commercial was perfectly timed: “This week, Republicans seized on Mr. Obama's appearance on NBC's 'Late Night with Jimmy Fallon' to paint him as a president who enjoys the trappings of office but hasn't done enough to rescue average Americans from joblessness or rising gasoline prices." ${ }^{58}$ Countless others claimed that the spot actually strengthened Obama's cool celebrity reputation. One YouTube viewer posted, "Seriously, I cannot be the only one who thinks Obama is one cool guy after this ad." 59 A political blogger for Esquire magazine admitted: "I don't know how this ad is supposed to work ... Young people are going to wonder why the old boring white guys are trying to harsh the national mellow." 60

\footnotetext{
${ }^{56}$ Tim Hanrahan, “Top Web Ads: 'Cool' and 'One Chance' Climb up Charts,” Washington Wire (blog), Wall Street fournal, April 30, 2012, http://blogs.wsj.com/washwire/2012/04/30/top-web-ads-cool-one-chance-climb-up-charts/\#.

${ }^{57}$ Kirk Faulkners posted: "Totally gonna vote for President Obama again, but this ad actually does make a good point. I know he is very cool and of the people and all that but you're gonna go on Jimmy Fallon? Really? The Presidential office definitely used to have a little more decorum [my emphasis]." Comment on "Cool" in Huff Post Social News Comments, Huffington Post, May 7, 2012, accessed September 1, 2013, http://www.huffingtonpost.com/2012/04/26/obama-celebrity-ad-americancrossroads-cool-video_n 1455413.html (this comment has since been removed).

${ }_{58}$ O’Connor, "Obama Campaign 'Flailing," Washington Wire (blog), Wall Street fournal, April 27, 2012, http://blogs.wsj.com/washwire/2012/04/27/romney-camp-says-obama-campaign-flailing/.

${ }^{59}$ YouTube comment by "gunnersfc14," September 2012, http://www.youtube.com/watch?v=lhXGkeMdOJs.

${ }^{60}$ Charles P. Pierce, "Karl Rove is a Slithering, Leprous Amphibian from Hell," The Politics Blog, Esquire, September 27, 2012, http://www.esquire.com/blogs/politics/american-crossroads-obama-cool-ad-8412675 (my emphasis).
} 
The confusion cited by numerous viewer comments demonstrated that the equivalence of this commercial was difficult for many to reconcile. One possible reason was that audiences with a particular knowledge of Obama's iconic moments in office might have recognized their miscontextualization. Indeed, a substantial factual blunder happens during the commercial's closing frames at its key moment of resolution. The final sequence in "Cool" suggests that Obama's appearance on Fallon's late-night show was simply gratuitous, but in reality its purpose was to gain media attention for the president's announcement of his plan to help struggling students by prohibiting increases on Stafford Student Loans.

The commercial's second misstep may have been that it appeared to reprimand the very youth it sought to entice by singling out their supposed mistake in choosing the fun candidate. In reminding them that the flailing economy had negatively impacted their hard work in college, the GOP super PAC claimed that Obama's coolness came at the expense of those who voted for him. In this way, the commercial can be read as a parental-sounding, finger-wagging, "I told you so." One particularly articulate YouTube commentator reads the spot this way and also points out the hegemonic values communicated through "Cool" that he or she saw as reflecting the larger Republican agenda:

Amusingly lame appeal to the youth vote. But of course young voters know that the jobless problem is the result of George W.'s Presidency, not Obama's. Obama is the one who stopped the economic slide and is slowly seeing it turn around. Obama is the one who is on young people's side when it comes to college loans, women's rights, and middle class mobility. And yes, he is way cooler than paternalistic, robot Rom. ${ }^{61}$

Lastly, viewers' responses indicate that the commercial's attempt to discredit the president with outdated musical and visual pop signifiers that were not in the slightest bit "cool" proved unsuccessful. While the synthesized pop and R\&B sounds and the grainy computer graphics were likely used in an ironic way to make Obama's cool celebrity status appear tacky, the attempt backfired as many claimed that this spot only confirmed his coolness. Donald Trump, a vocal Republican and celebrity in his own right, told MSNBC: "I thought it was a terrible ad by the Republicans, it made Obama bigger than life ... when I first saw it, I thought the Democrats put it out." ${ }^{\prime 2}$ Another online commenter proclaimed, "I love this Ad. Why? It's not quite doing what the strategists wish. They're showing how current and up to date President Obama is. A Celebrity . " ${ }^{63}$ Another said, "They hate that fact that our prez is real people, funny and talented. Haterz gonna hate. I love the ad and it won't work. It only makes the president look even cooler. Can you see Mitt do this?" ${ }^{64}$ In the Washington Post a leadership expert noted,

to dismiss President Obama in 2012 as merely a celebrity seems lame and unconvincing, akin to dismissing President Reagan in 1984 as little more than a Hollywood star. It dodges both the relevance and reality of significant policy differences while acknowledging the personal charisma that makes the one candidate so compelling. ${ }^{65}$

\footnotetext{
${ }^{61}$ YouTube comment by “mykb19,” September 2012, http://www.youtube.com/watch?v=lhXGkeMdOJs (my emphasis).

${ }^{62}$ Hanrahan, "Top Web Ads" (my emphasis).

${ }^{63}$ Comment by "as19810" in Huff Post Social News Comments, April 25, 2012, Huffington Post, accessed September 1, 2013, http://www.huffingtonpost.com/2012/04/26/obama-celebrity-ad-american-crossroads-cool-video_n_1455413.html, (my emphasis; this comment has since been removed).

${ }^{64}$ Comment by "Kels" in Huff Post Social News Comments, April 28, 2012, Huffington Post, accessed September 1, 2013. http://www.huffingtonpost.com/2012/04/26/obama-celebrity-ad-american-crossroads-cool-video n 1455413.html, (my emphasis; this comment has since been removed).

${ }^{65}$ John Paul Rollert, "President Obama's 'Cool' Factor,” Washington Post, May 16, 2012, http://www.washingtonpost.com/national/on-leadership/president-obama-is-cool-and-thats-a-goodthing/2012/05/16/gIQA3DY0TU story.html.
} 
In conjunction with the election's final results, these and other similar comments suggest that the American Crossroads spot was largely ineffective in convincing young audiences that Obama's cool celebrity image was a problem.

\section{Branding, Popular Music, and Party Politics}

"We Are a Powerful Force" and "Cool” exemplify how the President's image—like those of so many other contemporary celebrity figures-had been formed around the rules of corporate branding. In fact, Obama's team had upstaged big-name brands just before his 2008 election by winning the Association of National Advertisers' "Marketer of the Year" award over corporate giants that included Nike, Apple, Coors, and Zappos.com. ${ }^{66}$ The award also earned him the designation of a "superbrand" from journalist and author Naomi Klein. ${ }^{67}$ Indeed, Obama's public image fit well within the definitions of a corporate brand. The American Marketing Association defines a brand and branding as:

a customer experience represented by a collection of images and ideas; often, it refers to a symbol such as a name, logo, slogan, and design scheme. Brand recognition and other reactions are created by the accumulation of experiences with the specific product or service, both directly relating to its use, and through the influence of advertising, design, and media commentary . . . A brand often includes an explicit logo, fonts, color schemes, symbols, [and] sound which may be developed to represent implicit values, ideas, and even personality. ${ }^{68}$

Commercials for the 2012 presidential election certainly aimed to shape the customer (i.e., constituent) experience through the signifiers they featured. "We are a Powerful Force" and "Cool" used the essential aspects of branding-political logos, exaggerated fonts, bright color schemes, culturally charged symbols, and pop cultural sounds - to contribute to or comment on the Obama brand. More specifically, they used an abundance of signifiers taken from popular music and celebrity culture, represented visually as well as sonically to drive home their agendas.

In keeping with the branding message of Obama's re-election campaign slogan, "Forward," "We are a Powerful Force" highlighted race, gender, age, and class distinctions to empower traditionally underrepresented groups with uplifting music and images. On the other hand, the American Crossroads' attempt to re-brand the president's image with its antagonistic appropriation of popular music tropes and negative message to voting youth appeared to many viewers to merely reaffirm hegemonic white, upperclass, middle-aged male authority. Consequently, marketers for American Crossroads learned the hard way that putting popular music in advertising can be problematic due to its evocative potential and rich polysemic tendencies. As demonstrated by the racial implications suggested in marketers' placement of Yello's "oh yeah" throughout the track, music familiar to audiences outside a commercial's context can create unexpected and unwanted equivalences with the on-screen images. ${ }^{69}$ So, despite the care that

\footnotetext{
${ }^{66}$ Naomi Klein, "Naomi Klein on How Corporate Branding Has Taken Over America," The Guardian, January 16, 2010, book excerpt from No Logo, $10^{\text {th }}$ anniversary edition (London: Fourth Estate, 2010),

http://www.theguardian.com/books/2010/jan/16/naomi-klein-branding-obama-america.

${ }^{67}$ Ibid.

68 "Dictionary," American Marketing Association, http://www.marketingpower.com/_layouts/dictionary.aspx?dLetter=B (my emphasis).

${ }^{69}$ Nike's "Revolution in Motion" commercial provides an exemplary case study of the consequences of using pre-existing music in advertising. The spot featured a version of the Beatles' iconic 1968, counterculture anthem, "Revolution," and caused considerable backlash from audiences. It even prompted litigation from the living Beatles who did not approve its use in the spot. See Klein, As Heard on TV, 23-39.
} 
strategists took to punctuate the seriousness of the GOP's message about America's economic crisis with key moments of silence, viewers instead seemed to cling to the sections featuring the flashy images and glitzy musical track. One viewer confirms: "This ad makes the President look really cool! The GOP is counting on young viewers to bother reading the information at the end. Instead, most will remember the images and the music." ${ }^{70}$

Glenn T. Hubbard and Elizabeth Crisp Crawford warn that music should be used mindfully in political advertising due to evidence that it has the potential to overpower the candidate's message. ${ }^{71}$ Indeed, viewer comments about "Cool" illustrate the power (and overpowering effects) of its pop signifiers, demonstrating the degree to which they became unmanageable for marketers who did not fully understand what they had the potential to communicate. ${ }^{72}$ It is obvious, then, that in their foregrounding of the musical track for much of the spot—specifically its rowdy R\&B and pop sounds—marketers for American Crossroads actually undermined the party's agenda: in the attempt to abstract pop's musical signifiers, the super PAC spot unintentionally linked them more strongly with positive connotations of Obama's cool celebrity persona. ${ }^{73}$

From the opposite vantage point, "We are a Powerful Force" was successful in its more subtle use of pop's tropes. While the music literally and metaphorically drove the commercial's motion "forward," the image of Alicia Keys was arguably more connotative of contemporary mainstream popular music than the soundtrack itself. What was perhaps most noticeable about the music here was that marketers were careful to negotiate the boundaries between creating a typical political commercial soundtrack and making something slightly more cutting-edge. While some might argue that its favoring of more youthful pop sounds does not necessarily make it innovative since it avoids adherence to a specific genre, I would argue that this precisely why the spot proved agreeable: "We Are a Powerful Force" remains consistent with traditional political advertising practices by favoring a bland pop-ish musical track that would not detract from the Democratic party's intended message. In this way, the commercial adheres to the sonic rules for political advertising discussed by Hubbard and Crawford while still effectively foregrounding cultural signifiers tied to popular music at critical moments.

Those with discerning ears might also notice that the musical track in the OFA commercial does not sound like the R\&B performed by Keys, nor the soul or hip hop Obama himself claimed to admire. ${ }^{74}$ As Gorzelany-Mostak argues, the president had already fostered a tenuous relationship with "black" musics

\footnotetext{
${ }^{70}$ Comment by "bensisco" in Huff Post Social News Comments, April 30, 2012, Huffington Post, accessed September 1, 2013. http://www.huffingtonpost.com/2012/04/26/obama-celebrity-ad-american-crossroads-cool-video_n_1455413.html, (my emphasis).

${ }^{71}$ Glenn T. Hubbard and Elizabeth Crisp Crawford, "Music in Political Advertisements: Music to the Ears or Background Noise? A Study of Music's Influence on Message-Relevant Thinking," Fournal of Radio E Audio Media 15:2 (2008): 167-181, http://dx.doi.org/10.1080/19376520802397276.

${ }_{72}$ The most notorious case of marketers losing control of popular music signifiers happened in 1989 when PepsiCo Inc. licensed Madonna's "Like a Prayer" for their “A Generation Ahead” campaign. Executives failed to view Madonna's music video for the song and ended up pulling their commercial after viewers realized that the racial, religious, and sexually charged tropes composed into the music and portrayed in the video could be deciphered in the spot as well. See Phil Dusenberry's account of the backlash in Then We Set His Hair on Fire: Insights and Accidents for a Hall of Fame Career in Advertising (New York: Penguin Group, 2005), 234.

${ }^{73}$ As mentioned above, I extend Schudson's theories about advertising's abstraction of visual signifiers to musical ones. Advertising, the Uneasy Persuasion, 214.

${ }^{74}$ Although hip hop had arguably become the predominant form of popular music by the twenty-first century, Obama confirmed his baby boomer status and affinity for soul by admitting he was from the pre-hip hop generation. Sway Calloway, "Barack Obama Gives a Shout-Out to Hip-Hop," MTV, September 28, 2008, http://m.mtv.com/news/article.rbml?id=1595820.
} 
and culture in the previous election. ${ }^{75}$ This would make its use here potentially problematic. I would point out, then, that while the spot sonically avoids being racially specific, it makes up for this with its images. Keys's presence works to represent marginalized cultures through visual markers of her status as a youthful R\&B musician, an African American, and a woman. The majority of Keys's fans and Obama's constituents shown on screen also work simultaneously to reinforce these targeted demographics.

Marketers for "We are a Powerful Force" thus favored visually specific pop musical signifiers over sonic ones. "Cool" obviously took the opposite approach, using showy and distracting pop sounds to mirror the "commotion" of Obama's celebrity coolness portrayed on screen. While the Obama camp used pop music tropes to signify energy and change, Romney's supporters employed them in an attempt to suggest Obama was ineffective.

Both parties also used pop music tropes to characterize and magnify specific aspects of Obama's personality. Schudson argues that in national advertising campaigns, "the person played is not the actor or athlete as a human being, but ... flattened into a celebrity persona." ${ }^{, 76} \mathrm{He}$ asserts that their lives and personalities are abstracted and reduced to a generic notion of celebrity. Robert Goldman and Steven Papson echo Schudson's sentiment and theorize that advertising effectively "hollow[s] out" celebrities, leaving us with a "simulation." 77 There is no question that the GOP ad attempted to "hollow out" Obama's personality in "Cool." The commercial made an even bigger political media spectacle out of existing spectacular moments in an effort to reveal what the party saw as inappropriate behavior. On the other hand, Obama's celebrity surrogate in "We Are a Powerful Force," Alicia Keys, represented the president as a down-to-earth person who cared about women's rights and actively participated in grassroots efforts to incite social change. This spot and others like it worked to portray the president not only as a complex and real human being, but also as one supported by "cool” yet powerful individuals. By adhering to what Kellner defined as the media's current "codes" (namely, its investment in celebrities and social media), the OFA thus expertly wielded the peppy track and images of music sensation Alicia Keys to achieve maximum results in the 2012 election. ${ }^{78}$ Unfortunately for Republicans, their rejection of the media spectacle backfired: by labeling Obama's cool celebrity reputation as harmful to his constituents in the hopes of advancing its own candidate's position, they unintentionally directed more negative attention to their opponent.

\section{Popular Music in Cool Politics}

In considering the two spots side-by-side, it is apparent how hurtful Obama's cool celebrity image had become to the Republican candidate, Mitt Romney. "Cool" can be read as an anxious attempt to demystify the spectacle created around the president's brand. What distanced Obama from his opponent was that the concept of coolness did not need to be fashioned or stretched to fit the president's persona. The commercials discussed here prove that this characteristic had already become a (largely) welcome and well-worn part of his celebrity image in the media. ${ }^{79}$ Furthermore, despite the fact that the two commercials have similar agendas to attract young and marginalized audiences, the outdated pop signifiers

\footnotetext{
${ }^{75}$ Gorzelany-Mostak, "Keepin' it Real.”

${ }^{76}$ Schudson, Advertising, the Uneasy Persuasion, 213.

${ }^{77}$ Goldman and Papson, Nike Culture, 32.

${ }^{78}$ Kellner, Media Spectacle, 160.

${ }^{79}$ Kellner, "Barack Obama and the Celebrity Spectacle," 715-741.
} 
and miscontextualization of snippets taken from Obama's media headlines reveal the failure of the super PAC ad, and by extension the Republican Party, to successfully deploy the correct strategies to reach key marginalized and millennial voters. Finally, by agreeing that Obama was indeed "cool" and that his coolness was a negative quality, Republicans unintentionally implied that Romney was not cool. While "We are a Powerful Force" worked to bolster the president's multifaceted cool celebrity image, "Cool" made Romney appear increasingly one-dimensional and un-hip.

These two spots represent a small cross section of the many television and Internet commercials that featured popular culture tropes for the 2012 presidential race. Both parties made numerous commercials with well-known celebrities and footage from media headlines to remind audiences about the implications of having a cool celebrity as president. By 2012 the increasing cultivation of, and reliance on, the political media spectacle had grown to the point that the spectacle itself had become a well-worn trope. As the analysis above demonstrates, the use of the media and its spectacle, paired with the sights and sounds of American popular music, reveal a shift in political advertising practices in the twenty-first century. ${ }^{80}$ And despite the fact that pop culture's signifiers still prove tricky to incorporate, they are no longer off limits to political commercials. In this second decade of the new millennium, American audiences will surely witness popular music in increasingly high-profile roles in political advertising, allowing us to further realize the extent that popular culture continues to shape and be shaped by all facets of American media and (its) politics.

\section{Bibliography}

Abadi, Cameron. "Obama Ist Klein Berliner: Fifty Years after JFK's Visit, and Five Since His Own, Obama Returns to Berlin—to a Much Different Mood.” New Republic. June 18, 2013. Accessed August 11, 2014. http://www.newrepublic.com/article/113544/obamas-berlin-visit-2013-wont-be-anything2008.

American Crossroads. “About.” Accessed June 1, 2015, http://www.americancrossroads.org/about/.

American Marketing Association. "Dictionary.” Accessed September 1, 2013. http://www.marketingpower.com/_layouts/dictionary.aspx?dLetter=B.

Calloway, Sway. "Barack Obama Gives a Shout-Out to Hip-Hop.” MTV. September 28, 2008. Accessed June 12, 2014. http://m.mtv.com/news/article.rbml?id=1595820.

Consequence of Sound. "A History of Campaign Songs." November 5, 2012. Video Clip. Accessed August 12, 2014. http://consequenceofsound.net/2012/11/a-history-of-presidential-campaign-songs/2/.

C-Span. "Clinton Appearance on Arsenio Hall Show." June 3, 1992. Accessed August 12, 2014. http://www.c-span.org/video/?26472-1/clinton-appearance-arsenio-hall-show.

Dusenberry, Phil. Then We Set His Hair on Fire: Insights and Accidents for a Hall of Fame Career in Advertising. New York: Penguin Group, 2005.

Ebony. "[Watch] Alicia Keys', 'We are a Powerful Force.” Accessed September 9, 2013. http://www.ebony.com/video/news-views/watch-alicia-keys-we-are-a-powerfulforce\#axzz2ePGCij7G.

\footnotetext{
${ }^{80}$ As mentioned above, while popular music has been a part of campaign life for more than a century, it was not until Obama's candidacy that it noticeably infiltrated political commercials. The medium of the Internet is at least partially responsible for this, since the creative, financial, and quantitative restrictions on circulating commercials via the Internet are considerably lighter than the long-established ones imposed by television.
} 
Ferris Bueller's Day Off. DVD. Directed by John Hughes. 1986; Los Angeles, CA: Paramount Pictures, 1999.

Fink, Robert W. Repeating Ourselves. Berkeley: University of California Press, 2005.

Ford, Phil. Dig: Sound and Music in Hip Culture. Oxford: Oxford University Press, 2013.

Funny or Die. "Paris Hilton Responds to McCain Ad." Last modified August 5, 2008.

http://www.funnyordie.com/videos/64ad536a6d/paris-hilton-responds-to-mccain-ad-rom-parishilton-adam-ghost-panther-mckay-and-chris-henchy?playlist $=210399$.

Frank, Thomas. The Conquest of Cool: Business Culture, Counterculture, and the Rise of Hip Consumerism. Chicago: University of Chicago Press, 1997. http://dx.doi.org/10.7208/chicago/9780226924632.001.0001.

GGMB, Inc. "About: Creating Real and Lasting Change in the World.” Accessed August 12, 2014. http://www.gmmb.com/about/.

Goldberg, Adam. "Obama Celebrity Ad: American Crossroads 'Cool’ Video Slams President Over Fame, Economy." Huffington Post. Last modified April 26, 2012. http://www.huffingtonpost.com/2012/04/26/obama-celebrity-ad-american-crossroads-coolvideo_n_1455413.html.

Goldman, Robert and Stephen Papson, Sign Wars: The Cluttered Landscape of Advertising. New York: Guilford Press, 1996.

—_ Nike Culture: The Sign of the Swoosh, London: Sage Publications, 1998.

Goodwin, Andrew. Dancing in the Distraction Factory: Music Television and Popular Culture. Minneapolis: University of Minnesota Press, 1992.

Gorzelany-Mostak, Dana. “Keepin' it Real (Respectable) in 2008: Barack Obama's iPod as Proof of Cultural Blackness.” Unpublished manuscript, 2012.

Hanrahan, Tim. “Top Web Ads: 'Cool' and 'One Chance' Climb up Charts.” The Wall Street Journal: Washington Wire. Accessed September 1, 2013, http://blogs.wsj.com/washwire/2012/04/30/top-webads-cool-one-chance-climb-up-charts/\#.

HardPin Media. “About.” Accessed September 9, 2013. http://www.hardpinmedia.com.

Hubbard, Glenn T. and Elizabeth Crisp Crawford, "Music in Political Advertisements: Music to the Ears or Background Noise? A Study of Music's Influence on Message-relevant Thinking," Journal of Radio E Audio Media 15:2 (2008): 167-181.

Huffington Post. “GOP War on Women.” Accessed July 30, 2013. http://www.huffingtonpost.com/news/gop-war-on-women.

Huffington Post Entertainment. “President Obama Sings Al Green’s 'Lets Stay Together,' Sales Jump 490\%.” Last modified January 27, 2012. http://www.huffingtonpost.com/2012/01/27/president-obama-singsal-green-lets-stay-together-sales-jump_n_1236428.html.

Huffington Post Politics. Comments on "Cool." Accessed September 1, 2013. http://www.huffingtonpost.com/2012/04/26/obama-celebrity-ad-american-crossroads-coolvideo_n_1455413.html.

Huffington Post Politics, "McCain Ad Links Paris Hilton, Britney Spears To Obama," Last modified August 2, 2008, http://www.huffingtonpost.com/2008/07/30/mccain-ad-links-paris-hil_n_115841.html.

Kasperkevic, Jana. "Another Day, Another Ad, Another Celebrity Endorsement." Houston Chronicle. Accessed June 12, 2014. http://blog.chron.com/txpotomac/2012/10/when-it-comes-to-campaign-adsbarack-obama-is-the-celebrity-president/\#7972101=0. 
Kellner, Douglas. "Barack Obama and Celebrity Spectacle." International Journal of Communication 3 (2009). 715-741.

- Media Spectacle. New York: Routledge, 2003.

Klein, Bethany. As Heard on TV: Popular Music in Advertising, Burlington: Ashgate Publishing Company, 2009.

Klein, Naomi. "Naomi Klein on How Corporate Branding Is Taking over America." The Guardian. Last modified January 16, 2010. http://www.theguardian.com/books/2010/jan/16/naomi-klein-brandingobama-america.

Love, Joanna. "From Cautionary Chart-Topper to Friendly Beverage Anthem: Michael Jackson's 'Billie Jean' and Pepsi's 'Choice of a New Generation' Television Campaign.” Journal of the Society for American Music 9 (2015): 178-203.

McCarthy Hennings Whalen, Inc. "Past and Current Clients." Accessed May 25, 2015. http://www.mhmediadc.com/clients.aspx.

Meier, Leslie M. "Promotional Ubiquitous Musics: Recording Artists, Brands, and "Rendering Authenticity." Popular Music and Society 34, 4 (2011): 399-415. http://dx.doi.org/10.1080/03007766.2011.601569.

Music in Advertising: Commercial Sounds in Media Communication and Other Settings. Edited by Nicolai Graakjaer and Christian Jantzen, 141-167. Aalborg: Aalborg University Press, 2009.

NBC News. "Presidential election results." Accessed September 1, 2013. http://elections.nbcnews.com/ns/politics/2012/all/president/\#.Uiy6iLzk-7d.

Nelson, Angela. "Popular Culture in the Age of Obama." In The Iconic Obama 2007-2009: Essays on Media Representations of the Candidate and New President. Edited by Nicholas A. Yanes and Derrias Carter, 915. Jefferson: McFarland \& Company, 2012.

O’Connor, Patrick. "Romney Team Says Obama Campaign 'Flailing."” The Wall Street Journal: Washington Wire. Last modified April 27, 2012. http://blogs.wsj.com/washwire/2012/04/27/romney-camp-saysobama-campaign-flailing/.

Oray, Patrick B. "Myth, Symbol, and the Branding of an American Presidency." In The Iconic Obama 20072009: Essays on Media Representations of the Candidate and New President. Edited by Nicholas A. Yanes and Derrias Carter, 28-42. Jefferson: McFarland \& Company, 2012.

Organizing for Action. “About.” Accessed July 31, 2013, http://www.barackobama.com/about/aboutofa? source $=$ footer-nav.

Peters, Jeremy W. "Aggressive Ads for Obama at the Ready." The New York Times. Last modified May 8, 2012. http://www.nytimes.com/2012/05/09/us/politics/obamas-media-team-has-aggressive-ads-atthe-ready.html? pagewanted $=$ all\& $\mathrm{r}=1 \&$.

Pierce, Charles P. "Karl Rove is a Slithering, Leprous Amphibian from Hell.” Esquire: The Politics Blog. Last modified September 27, 2012. http://www.esquire.com/blogs/politics/american-crossroads-obamacool-ad-8412675.

Powers, Devon. "Strange Powers: The Branded Sensorium and the Intrigue of Musical Sound.” In Blowing up the Brand: Critical Perspectives on Promotional Culture. Edited by Melissa Aronczyk and Devon Powers, 285-306. New York: Peter Lang Publishing, 2010.

Rap Dose: Your Daily Fix of Urban Entertainment. “Alicia Keys: 'We Are A Powerful Force' (Obama For America)." Accessed September 9, 2013. http://rapdose.com/2012/09/27/alicia-keys-we-are-apowerful-force-obama-for-america. 
Rollert, John Paul. “President Obama's 'Cool' Factor.” The Washington Post. May 16, 2002. Accessed August 10, 2014. http://www.washingtonpost.com/national/on-leadership/president-obama-is-cooland-thats-a-good-thing/2012/05/16/gIQA3DY0TU_story.html.

Rutledge, Pamela. "How Obama Won the Social Media Battle in the 2012 Presidential Campaign." The Media Psychology Blog. Last modified January 25, 2013. http://mprcenter.org/blog/2013/01/25/howobama-won-the-social-media-battle-in-the-2012-presidential-campaign/.

Schudson, Michael. Advertising, the Uneasy Persuasion: Its Dubious Impact on American Society. New York: Basic Books, 1984.

Sheets, Diana E. "Obama's 2012 Victory: The Demographic Becomes the Narrative." Huffington Post Politics. Last modified December 21, 2012. http://www.huffingtonpost.com/dr-diana-esheets/obamas-2012-victory-the-demographic-becomes-the-narrative_b_2341438.html.

Smythe, Dallas W. "On Critical an Administrative Research: A New Critical Analysis.” Journal of Communication 33 (1983): 117-127.

Taylor, Timothy. "The Changing Shape of the Culture Industry; or, How Did Electronica Music Get into Television Commercials?.” Television \& New Media (2007): 235-258. http://dx.doi.org/10.1177/1527476407301837.

- The Sounds of Capitalism: Advertising, Music, and the Conquest of Culture. Chicago: University of Chicago Press, 2013.

The Dallas Weekly. "Alicia Keys: 'We are a Powerful Force' - New Video from Obama for America." Last modified September 28, 2012.

http://www.dallasweekly.com/arts and_entertainment/article_78d05528-08d9-11e2-aafe0019bb30f31a.html? mode $=$ image $\&$ photo $=0$.

The New York Times. “The Campaign Against Women.” SR 10. May 20, 2012.

Vibe. “Alicia Keys Performs 'Girl on Fire’ at 2013 Inaugural Ball.” Last modified January 22, 2013. http://www.vibe.com/article/alicia-keys-performs-girl-fire-2013-inauguration-ball.

Weiner, Rachel. "Obama unveils new campaign slogan: 'Forward." The Washington Post, Last modified April 30, 2012. http://www.washingtonpost.com/blogs/the-fix/post/obama-unveils-new-campaignslogan-forward/2012/04/30/gIQA3SrbrT_blog.html.

Williams, Raymond. "Advertising: The Magic System.” In Media Studies: a Reader. Edited by Paul Marris and Sue Thornham, 704-709. New York: New York University Press, 2000.

Williamson, Judith. Decoding Advertisements: Ideology and Meaning in Advertising. London and New York: Marion Boyars, 1978.

Women for Obama. "Alicia Keys: 'We are a Powerful Force." Organizing for Action. Accessed March 1, 2013. http://www.barackobama.com/women/videos.

Yello. "Oh Yeah.” Universal Music Strategic Marketing, 2009. MP3 file. Downloaded September 6, 2013. Amazon.

YouTube. American Crossroads. "Cool.” April 26, 2012. Video clip and comments. Accessed February 15, 2012. www.Youtube.com. http://www.youtube.com/watch?v=lhXGkeMdOJs.

YouTube. "Ronald Reagan TV Ad: 'It's morning in America again.'” November 12, 2006. Video Clip. Accessed September 9, 2013. www.Youtube.com, http://www.youtube.com/watch?v=EU-IBF8nwSY.

YouTube. Comments on "We are a Powerful Force." November 2012. Accessed May 11, 2014. $w w w . Y o u t u b e . c o m$. http://www.youtube.com/watch?v=HB7XQw3k7uc. 


\begin{abstract}
Barack Obama captured global attention in both presidential campaigns by using tropes from popular culture to build his public image. Obama's marketing team expertly wielded the media to publicize his fluency in pop culture trends, contributing to what Douglas Kellner called the political "celebrity spectacle." As Obama and his opponent, Mitt Romney, prepared for the 2012 election, media outlets, scholars, and political analysts fixated on the implications of the American President's undeniable "celebrity" status. Many were particularly concerned with Obama's media-generated reputation for being perceived as "cool" (in Thomas Frank's sense of the word) among youth and other marginalized voters. As a result, the theme of what I term Obama's "cool celebrity" status infiltrated commercials made by both major American parties.

This essay examines two representative commercials that foregrounded popular music's tropes to paint Obama, for better or for worse, as a "cool celebrity" president. By analyzing how these commercials employed the sights and sounds of popular music to drive their soundtracks and agendas, I investigate how they negotiated the lines between national brand and traditional political advertising. This article incorporates musicological inquiry with media and advertising theory to contribute to growing scholarship on popular music's role in American marketing practices.
\end{abstract}

